\title{
ETYCZNOŚĆ POSTĘPOWANIA REPREZENTANTÓW INSTYTUCJI PAŃSTWA I PRZEDSTAWICIELI BIZNESU
}

\section{WSTĘP}

Etyka biznesu stała się w ostatnich latach dyscyplina, której poświęca się wiele uwagi, badań i analiz naukowych. Zarówno teoretycy ekonomii, działający menedżerowie, jak i pozostała część społeczeństwa szukają odpowiedzi, w jaki sposób uprawiać etykę biznesu, aby mogła ona wywierać kluczowy, rzeczywisty wpływ na podejmowane w ramach praktyki gospodarczej działania. Apelowanie do sumienia, moralności i etycznych zachowań okazało się bowiem jak dotąd mało skuteczne, zwłaszcza w sytuacjach gdy w grę wchodzi interes własny. Jednym z powodów powstałej sytuacji jest brak we współczesnych społecznościach spoistości oraz zaniechanie przejmowania z przekazywanego przez tradycję wiążącego katalogu wartości, na którym mogłoby się oprzeć uzasadnienie norm etycznych. Sprawia to, że współczesne pluralistyczne społeczeństwa nie są normatywnym monolitem, przeciwnie, ludzie mają odmienne preferencje, a wyrastajace $z$ odrębnych tradycji i ufundowane na odmiennych systemach aksjologicznych etyki materialne w tych samych empirycznie kontekstach dochodzą do odmiennych ocen. Następstwem tych symptomów jest duża heterogeniczność modeli życia społecznego, które bezwzględnie mają takie samo prawo istnienia, pod warunkiem jednak, że nie narażają wolności innych ludzi. Pociaga to jednak za soba poszukiwanie wspólnych domen oraz wynegocjowanie kolektywnego stanowiska. Kwestie te opisał Karl-Otto Apel ${ }^{1}$, który w swoim opracowaniu zaproponował, by zdobytą w demokracjach parlamentarnych praktykę godząca stanowisko polityczne oraz zdolność negocjowania sporów ekonomicznych i społecznych zaliczyć do kategorii etyki społecznej.

Spełnienie przyjętych przez K.-O. Apla założeń narzuca jednak konieczność przekonania wszystkich stron, a więc zarówno instytucji państwowych, jak i organizacji gospodarczych i całego społeczeństwa, że przestrzeganie norm etycznych zapewnia osiagnięcie rzeczywistych efektów materialnych i moralnych. Problem w tym, że do kwestii etycznych wiele podmiotów

${ }^{1}$ K.-O. Apel, Etyka dyskursu jako etyka odpowiedzialności - postmetafizyczna transformacja etyki Kanta, Kraków1992, s. 5-36. 
podchodzi niejednolicie. Jak pisze Maria Ossowska²: „Różność ta bywała przedmiotem refleksji przede wszystkim w jednej ze szczególnie drastycznych swoich postaci, mianowicie w znanym przeciwstawieniu moralności jednostki i tej, którą rządzi się państwo, moralności utożsamianej w tym wypadku z moralnościa racji stanu". Cavour miał nawet powiedzieć, że gdyby dla siebie robił to, co robił dla Włoch, byłby uważany za łajdaka. Notabene frazeologizm moralności racji stanu przypisuje się $\mathrm{z}$ reguły odrodzeniu i łączy z nazwiskiem Machiavellego. Maria Ossowska ${ }^{3}$, odnotowuje również, że posługujący się takimi zwrotami, jak „Państwo rządzi się moralnościa kierowaną racją stanu”, „Grupa musi mieć inną moralność niż jednostki” itp., używaja zwrotów, których nie należy brać dosłownie, żadne bowiem grupy jako całość, a więc i państwo, nie sa sprawcami pewnych czynów ani autorami pewnych ocen czy norm, tymi sprawcami bowiem i autorami moga być tylko jednostki indywidualne. Zatem w obrębie grupy to jednostki indywidualne wpływają np. na kierunek polityki państwa, strategię i zachowanie jednostek gospodarczych i pozostałych podmiotów. Każdy człowiek będący w kolektywie podejmuje decyzje i jest w mniejszym lub większym stopniu wykonawcą ustaleń danego gremium, i to niezależnie od tego, czy jest przedstawicielem instytucji państwowej, spółki, organizacji społecznej czy menedżerem przedsiębiorstwa.

Dwoistość moralności często wykorzystywana jest do usprawiedliwienia nieetycznych postaw i uzasadniania złych intencji lub niekompetencji. Proceder ten jest zgoła bardzo niebezpieczny, ponieważ może być sposobnościa, by tłumaczyć w zasadzie wszystkie niemoralne, nieetyczne, nieekonomiczne decyzje. Dwoistość ta jest także bardzo niebezpieczna i z tego wzglę$\mathrm{du}$, że stwarza patologiczne związki we wszystkich relacjach społeczno-gospodarczych, ponieważ kto nauczył się stosować agresywną moralność, ten z wszelkim prawdopodobieństwem zastosuje ją, by bronić swej władzy, jeśli zostanie zagrożona. W efekcie stwarza to sytuację, w której stosunek etycznych zachowań państwa i przedstawicieli biznesu bywa zazwyczaj utożsamiany z kontrowersja, jaka ma zachodzić między dyrektywami polityki i etyki.

Celem opracowania jest wykazanie, że kwestie korelacji pomiędzy etycznie postępujacymi reprezentantami instytucji państwowych a etycznym postępowaniem przedstawicieli biznesu są niedostatecznie dostrzegane i doceniane oraz że wprowadzenie systemu etycznego ${ }^{4}$, złożonego z ocen obiektywnych, implikuje w efekcie etyczna samoregulację podmiotów społeczno-gospodarczych i rozwój ekonomiczny państwa.

${ }^{2}$ M. Ossowska, Podstawy nauki o moralności, PWN, Warszawa 1966, s. 380-388.

${ }^{3}$ Ibidem, s. 380.

${ }^{4}$ System etyczny, na wzór systemów ekspertowych, na ogół rozumiany jest jako podstawa normalizacji etycznej i ewaluacji etycznej. System taki ma zawierać usankcjonowaną warstwę normatywną (problem legitymizacji), warstwę empiryczną (np. empiryczne badania skutków w przypadku etyk konsekwencjalistycznych), dopracowaną operacjonalizację (połączenie warstwy normatywnej z empiryczna), system ma mieć możliwie wysoką wydajność ewaluacyjną i możliwie wysoki potencjał implementacyjny. 


\section{KONTROWERSJE ZWIĄZANE Z FUNKCJA I POWINNOŚCIĄ INSTYTUCJI PAŃSTWOWYCH WE WSPÓŁCZESNYCH GOSPODARKACH}

Instytucje państwowe przez system bodźców wywierających wpływ na określone zachowania oddziałują na procesy rozwoju i podejmowania konkretnych decyzji społecznych i gospodarczych. Sprawne instytucje warunkuja stabilność i kompatybilność wszystkich obszarów gospodarki. Jak stwierdza Zbigniew Staniek, w literaturze ekonomicznej, zwłaszcza w zakresie różnych nurtów ekonomii instytucjonalnej, nie ma zgody co do jednoznacznego i niebudzącego wątpliwości sprecyzowania terminu „instytucja”. Na ogół jego zdaniem traktuje się instytucje jako „obowiązujące reguły gry, struktury zarządcze wpływajace na podmioty-graczy, sposoby prowadzenia gier czy sposoby narzucania reguł i ich egzekwowania, sposoby myślenia i postępowania ludzi ujawnione w zachowaniach i zwyczajach grup i jednostek, systemy społecznych interakcji, obowiąujące systemy przekonań i oczekiwań, wzorce zachowań itd.”. Jednakże najbardziej znaną i często cytowaną definicją instytucji jest definicja Douglasa C. Northa ${ }^{6}$, który regulację tłumaczy jako „[...] reguły gry w społeczeństwie, czy bardziej formalne, skonstruowane przez ludzi ograniczenia, które kształtują ich wzajemne interakcje. W konsekwencji określaja one strukturę bodźców w procesie wymiany gospodarczej, politycznej czy społecznej [...]".

Instytucjonalne reguły można i należy ewaluować, ale zgodnie z demokratyczna procedura i tak, aby konstytuowały ramy prowadzenia polityki publicznej, w tym polityki gospodarczej. Ignorowanie ich, odroczenie lub wycofanie podważa podstawy prowadzenia działalności gospodarczej i zaufanie do państwa. Deprecjonowanie instytucjonalnych reguł w imię sprawności rządzenia to prosta droga do nieprzestrzegania umów i zobowiązań we wszystkich relacjach, a więc państwo-obywatele, państwo-przedsiębiorstwo, obywatelobywatel, przedsiębiorstwo-konsumenci, przedsiębiorstwo-przedsiębiorstwo. Długofalowym następstwem lekceważenia standardów etycznych jest słabość państwa i brak wzajemnego zaufania. Przykładem jest zapoczątkowany na przełomie roku 2007 i 2008 kryzys finansowy, który objął następnie całą sferę społeczno-gospodarczą. Jego nieetyczne podłoże spowodowało znaczny wzrost niezadowolenia społecznego i politycznych napięć w wielu krajach, szczególnie w Stanach Zjednoczonych oraz krajach UE. Wywołało to wzmożoną dyskusję dotycząca nie tylko roli, wpływów i kontroli państwa w gospodarce rynkowej, lecz także reprezentowanych przez przedstawicieli instytucji państwowych norm etycznych. Ważkim przedmiotem dyskursu stał się także stopień intensywności oddziaływania państwa na rynek, tym bardziej że pozostało sporo problemów, które nie zostały rozwiązane ani przez liberałów, ani przez zwo-

${ }^{5}$ W. Paco (red.), Szkice z dynamiki i stabilizacji gospodarki, Oficyna Wydawnicza, Warszawa 2009, s. 122.

${ }^{6}$ D. North, Institutions, Institutional Change and Economic Performance, CUP, Cambridge 1994, s. 3. 
lenników gospodarki o orientacji podażowej, ani zwolenników różnych odmian keynesizmu, ani też zwolenników globalnego sterowania popytem. Do kwestii tych należą głównie: rozwiązanie problemu bezrobocia - walka z ubóstwem i wykluczeniem społecznym; stworzenie warunków do uczciwej konkurencji; polityka społeczno-gospodarcza państwa wobec procesów globalizacyjnych; ograniczenie zużycia surowców naturalnych i ochrona środowiska. Powyższy wykaz nierozwiązanych, notabene bardzo trudnych, problemów pozwala stwierdzić, że zagadnienia te wymagaja jak najszybszych rozstrzygnięć przez państwo i że staną się, a w zasadzie już się stały, podstawą innego postrzegania roli państwa, przede wszystkim jako głównego podmiotu niwelującego nierówności społeczne.

Jak zauważa Zdzisław Sadowski, już George Soros dostrzegł prawdę nienowa, że kapitalistyczny system rynkowy ma tendencję do wytwarzania coraz większych nierówności społecznych, tworzenia obszarów nędzy i spychania znacznych grup ludności na margines życia społecznego. System rynkowy nie daje też sobie rady z globalnymi zagrożeniami dla przyszłości świata, do których już doprowadziło (i nadal prowadzi) destrukcyjne oddziaływanie rozwoju przemysłu na środowisko naturalne. Obrona jest więc konieczna, a prowadzić ja musi ostatecznie państwo, jako naczelna organizacja społeczna. Według Sadowskiego ${ }^{7}$ chodzi o to, że państwa nie tylko nie można osłabiać, lecz we wspólnym interesie społecznym trzeba je wzmacniać - nie jego władczość i zdolność zarzadzania, lecz jego zdolność do wspomagania gospodarki rynkowej i ograniczania jej negatywnych następstw.

Tymczasem obecna sytuacja jest nie do utrzymania. Żadnego z większych współczesnych kryzysów nie udało się państwom skutecznie zahamować ani nie uda się powstrzymać, jeśli nie zostanie pokonany kryzys współczesnej demokracji i logiki władzy. Przyjęty bowiem system sprawowania władzy, szczególnie w krajach o liberalnej i neoliberalnej gospodarce, po długim okresie istnienia generuje dużo więcej problemów niż ich rozwiązuje. W ostatnich latach przyjęty system sprawowania władzy państwowej nie może nawet podołać największym kryzysom, które sam stwarza, ewentualnie tylko odsuwa je w czasie. Problem ten notabene jest bardzo aktualny w Polsce. W trafny sposób sytuację tę objaśnia Pierre Bourdieu, konstatując: „[...] ci, którym powiodło się i osiagnęli sukces w działaniach o kapitały główne, gruntują swą przewagę poprzez stosowanie przemocy symbolicznej. Jest ona oparta na zbiorze ogólnie uznawanych, czy choćby deklarowanych przekonań dotyczących prawomocności władzy, typem asymetrycznej relacji między rządzącymi a rządzonymi (relacja podporządkowania), której z racji jej utrwalenia się w społecznej strukturze wymiany, nie towarzyszy ani ich sprzeciw, ani zgoda. Prymat zyskuje strona posiadajacca współmiernie większe środki promocyjne. Problemem staje się natomiast sposób kontroli władzy przez grupy dysponujące mniejszymi zasobami kulturowymi (wiedza) czy społecznymi (zdolnościami integracyjnymi)". W efekcie często mamy do czynienia z sytuacja, w której establishment poli-

${ }^{7}$ Z. Sadowski, Eseje o gospodarce, PTE, Bellona, Warszawa 2000, s. 16-17.

${ }^{8}$ P. Bourdieu, L. D. Wacquant, Zaproszenie do socjologii refleksyjnej, Oficyna Wydawnicza, Warszawa 2001, s. 162-163. 
tyczny i gospodarczy z jednej strony występuje w roli wykonawcy i nadzorcy norm prawnych, z drugiej natomiast - osiaga przewage symboliczna nad innymi przez umiejętne wykorzystanie zakumulowanego kapitału integracyjnego. Trudno więc dziwić się, że postrzegany jest jako grupa monopolizująca przemoc w celach wyraźnie różnych od deklarowanych. Wraz z tym przemoc (częściowo) traci swój iluzjonistyczny charakter, a społeczni uczestnicy, choć niezdolni do oporu, wyzbywają się złudzeń dotyczących związków, łączących deklarowane (przez władzę) cele i respektowane przez nich normy. System zostaje zainfekowany niewiarą w skuteczność mechanizmów (auto)naprawy. Zarazem jednak ci, którzy chcąc nie chcąc go współtworzą, uprzednio często nie mają innej alternatywy, natomiast potem koszty sprzeciwu są dla większości zbyt wysokie ${ }^{9}$. Zaburzenia te w rezultacie często skutkuja etycznie dyletanckim, odstraszającym i fałszywym moralizmem, który gubi etykę równie szybko i skutecznie, jak moralnie niewrażliwe dążenie do zysku. Tymczasem aby postępował rozwój społeczno-gospodarczy, muszą występować określone zasady etyczne, obowiązujące wszystkie podmioty w gospodarce, które dzięki nim mogą uzyskać summum bonum: zysk, trwałość i rozkwit przedsiębiorstwa oraz dobrobyt i sukces indywidualny.

\section{ETYKA. INSTYTUCJE PAŃSTWOWE. BIZNES}

W żadnej gospodarce państwo nie jest pozbawione roli inwestora, właściciela $^{10}$, podmiotu gospodarujacego sektorem publicznym (jest to w rzeczywistości niemożliwe i praktycznie absurdalne). Państwo jest także podmiotem gospodarczym z racji pełnienia roli kupującego (zamówienia publiczne), jak też pełnienia funkcji redystrybutora budżetu. Daje to podstawę do stwierdzenia, że państwo jest i być powinno zarówno podmiotem gospodarczym, a więc uczestnikiem rynku, jak i podmiotem politycznym regulującym funkcjonowanie rynku, prawodawca i sekwestratorem prawa.

Aktywności państwa w sferze gospodarki nie należy rzecz jasna rozumieć jako stymulanta etatyzmu, lecz jako uświadomienie konieczności wspomagania rynku w dążeniu do celów, których nie osiaga się w wyniku jego samorzutnego działania. Stanowisko to przyjmuje także John Kenneth Galbraith, który włączanie państwa w gospodarkę uzasadnia czterema następujacymi czynnikami:

- po pierwsze, potrzebna jest bieżąca i długookresowa ochrona naszej planety, działania określane powszechnie jako zapobieganie niszczeniu środowiska naturalnego;

9 A. Zybertowicz, Przemoc i poznanie. Studium z nie-klasycznej socjologii wiedzy, Wyd. UMK, Toruń 1995, s. 169.

${ }^{10} \mathrm{~Np}$. w uchodzących za bardzo liberalne państwo - Stanach Zjednoczonych, m.in. poczta jest państwowa (United States Postal Services - USPS), działa jako agenda rządowa, która ma wciąż zapewniony częściowy monopol na przesyłanie listów. 
- po drugie, potrzebna jest ochrona tych spośród zatrudnionych w aparacie produkcyjnym, którzy są szczególnie narażeni na szkodliwe skutki machiny gospodarczej;

- po trzecie, w gospodarce skłonność do wytwarzania i sprzedawania dóbr i usług z technicznymi wadami lub fizycznie szkodliwych nie jest przypadkowa;

- po czwarte, system sam w sobie zawiera mechanizmy grożące samozagładą pod wpływem jego działania.

Zdaniem J. K. Galbraitha ${ }^{11}$ każdy z tych czynników wywołuje ostry konflikt w aspekcie ideologicznym między tymi, którzy traktują system jako zupełnie niezależną siłę i siebie jako zasłużenie przez ten system wynagradzanych, a tymi, którzy opowiadają się za działaniami ochronnymi lub korekcyjnymi.

Według Zbigniewa Madeja ${ }^{12}$ nieosiagalna jest „[...] pełna wolność polityczna, w pełni swobodna konkurencja i pełna wolność w wyborze szans. Bez ingerencji z zewnątrz wszystkim tym wolnościom grozi autodestrukcja, ale warto pamiętać również o tym, że ingerencja zewnętrzna może je zdusić”. W paralelny sposób zagadnienie to ujmuje Leszek Kołakowski, stwierdzając, że nie tylko przesadna wolność, lecz także rozszerzanie i konsekwentne stosowanie w całości zasad liberalnych przeobraża je w przeciwieństwa, co oznacza, że w pełni konsekwentne ich stosowanie jest po prostu niemożliwe ${ }^{13}$. Bardzo krytycznie kwestię właczania się państwa jako regulatora $\mathrm{w}$ gospodarkę przedstawia natomiast Grzegorz Kołodko ${ }^{14}$, konstatujac: że: „We wszystkich typach gospodarki rynkowej - ale na pewno więcej i częściej w państwowym niż neoliberalnym kapitalizmie - szerzy się klientelizm, którym państwowe regulacje i polityka rządowa wysługują się politycznym, biurokratycznym i biznesowym koteriom, zamiast korygować niedostatki rynku. Ma to tyleż wspólnego z rzetelnym interwencjonizmem, co neoliberalne kanty z uczciwymi interesami”.

Już w XIX w. David Hume ${ }^{15}$ podkreślał, że rozwiązania instytucjonalne w społeczeństwie demokratycznym i w gospodarce rynkowej powinny być oparte na przestrzeganiu trzech praw naturalnych: stabilności własności, transferu własności tylko w drodze zgody kupującego i sprzedającego, dotrzymywanie obietnic (umów). Dotrzymywanie obietnic jako jedno z trzech ważnych praw naturalnych wiąże się z uczciwością i moralnościa, zasadami etycznymi. Niebagatelnym w tym kontekście punktem odniesienia są problemy natury etycznej, a w szczególności kwalifikacja postępowania etycznego przedstawi-

11 J. K. Galbraith, Godne społeczeństwo. Program troski o ludzkość, Bellona, Warszawa 1999, s. 68 .

12 Z. Madej, Legitymizacja polityki gospodarczej w systemach rynkowych, w: B. Fiedor, Z. Hockuba (red.), VIII Kongres Ekonomistów Polskich, Nauki Ekonomiczne Wobec Wyzwań Wspótczesności, PTE, Warszawa 2009, s. 330.

${ }^{13}$ L. Kołakowski, Samozatrucie otwartego społeczeństwa, w: K. Popper, Społeczeństwo otwarte $i$ jego wrogowie, t. 1: Urok Platona, Niezależna Oficyna Wydawnicza, Warszawa 1987, s. III.

${ }^{14}$ G. Kołodko, Nowy pragmatyzm, czyli ekonomia i polityka dla przyszłości. Ekonomia dla przyszłości. Fundamentalne problemy teorii ekonomii i praktyki gospodarczej, PTE, IX Kongres Ekonomistów Polskich, Warszawa 2014, s. 34.

15 D. Hume, A Treatise of Human Nature, Clarendon Press, Oxford 1896 (1739), s. 526, http:??oll.libertyfund.org [dostęp: 29.07.2016]. 
cieli instytucji państwowych i wszystkich podmiotów rynkowych oraz skutki ich zachowań dla gospodarki.

Współcześnie jednym z symptomatycznych przykładów dyskusyjnych praktyk państwa, które z punktu widzenia sprawiedliwości społecznej wydają się nieetyczne, jest finansowanie wielkich prywatnych banków na począt$\mathrm{ku}$ ostatniego kryzysu gospodarczego publicznymi pieniędzmi. W Stanach Zjednoczonych i wielu państwach Europy Zachodniej upaństwowiono w ten sposób gigantyczne straty prywatnych przedsiębiorstw, praktycznie nic nie zmieniając w ich patologicznym działaniu. Uratowano gospodarkę przed bankructwem, ocalając przy tym wielu prezesów i właścicieli odpowiedzialnych za krańcowo ryzykowne transakcje, które spowodowały te straty. Podobnie było w Polsce. Aczkolwiek straty przedsiębiorstw nie zostały upaństwowione w sposób tak jawny, to jednak ich część została upubliczniona przez tzw. pakiet antykryzysowy. Za ochronę prywatnych przedsiębiorstw przed skutkami kryzysu częściowo zapłacił Skarb Państwa (m.in. w formie dopłat do płac urlopowanych pracowników), częściowo również pracownicy zobowiązani byli do korzystania z urlopów, gdy było to pracodawcy wygodne, oraz do pracy w nadgodzinach bez dodatkowej zapłaty, gdy przedsiębiorstwo miało zbyt dużo zamówień. Najtrudniejsze do zaakceptowania z moralnego punktu widzenia jest to, że w wielu przypadkach przyjęcie ciężaru przez pracowników nie wiązało się z żadnymi wyrzeczeniami ze strony właścicieli i menedżerów pogrążonych w kłopotach przedsiębiorstw. Efekt często jest taki, że prezesi nadal wypłacają sobie ogromne premie, dzięki dodatkowym zyskom osiagniętych kosztem pracowników oraz że wysiłkiem całego społeczeństwa przed skutkami kryzysu i bankructwa przedsiębiorstw zostały ochronione najbardziej uprzywilejowane ekonomicznie grupy właścicieli i menedżerowie na najwyższych szczeblach ${ }^{16}$.

Przejawem opisywanych tendencji jest wciąż zwiększająca się polaryzacja dochodowa i majątkowa społeczeństw. W przeświadczeniu Roberta Dahla to właśnie wynikające ze stosunków własności duże dysproporcje ujawniaja nierówności i silne konflikty społeczne. Twierdził, że: „Własność i kontrola przyczyniają się do powstawania wielkich różnic pomiędzy obywatelami pod względem bogactwa, dochodu, statusu, kwalifikacji, informacji, kontroli nad informacją i propaganda, dostępu do przywódców, a także do tego, że na ogół dają się przewidzieć szanse życiowe nie tylko dla dorosłych, ale ich dzieci, nawet tych jeszcze nienarodzonych. Różnice stąd płynące ułatwiają powstawanie poważnych nierówności w ich zdolnościach i szansach uczestnictwa jako obywateli w kierowaniu państwem"17. Analogicznie problem ten postrzegał Charles Lindblom, który uważał, że: „Ponieważ publiczne funkcje w systemie rynkowym znajduja się w rękach biznesmenów, to tym samym w ich rękach znajdują się praca, ceny, produkcja, wzrost, stopa życiowa oraz bezpieczeństwo ekonomiczne każdego z nas. Właśnie dlatego władza publiczna nie może być obojętna wobec tego, jak biznes wypełnia owe publiczne funkcje. Depresja, inflacja czy inne ekonomiczne plagi moga prowadzić do upadku władzy. Dlatego jednym z najważniejszych zadań rządu jest obserwowanie sposobu, w jaki

${ }_{16}$ J. Żakowski, Zawał. Zrozumieć kryzys, Polityka Spółdzielnia Pracy, Warszawa 2009, s. 8.

17 D. Dahl, A Preface to Economic Democracy, YUP, New Haven, CT, 1985, s. 55. 
biznesmeni wykonuja swoje zadania ${ }^{18}$. Budujące jest jednak, że odzwierciedlenie tych ostrzeżeń, choć jeszcze w niedużym stopniu, widać coraz wyraźniej $\mathrm{w}$ podjętych przez ekonomistów wysiłkach w kierunku wyprowadzania gospodarki rynkowej na porzucona poprzednio drogę zmniejszania nierówności i dysproporcji dochodowej i majątkowej społeczeństw.

Szeroko dyskutowane i wyświetlone rozbieżności między teorią ekonomii, przede wszystkim jej nurtem neoliberalnym, a wartościami ujętymi w założeniach etycznego gospodarowania spowodowały również, że duża grupa ekonomistów już od dłuższego czasu uważa, iż ekonomię należy uprawiać nie tylko jako naukę pomagająca wyjaśniać pewne zjawiska gospodarcze na podstawie konstrukcji i analiz matematycznych (teoria neoklasyczna), lecz także jako naukę pozwalającą zrozumieć dane procesy na podstawie syntetycznej analizy czynników wpływających na rozwój gospodarczy ${ }^{19}$. Przyjmując ten punkt widzenia, warto podjać rozważania dotyczące wartości i sposobu ich upowszechniania, zarówno w teorii ekonomii, jak też gospodarce, ale też ważne jest, aby nie gubić przy tym z pola widzenia ludzi, bieżących problemów społecznych, etycznych i moralnych, a więc nie skupiać się tylko na zagadnieniach efektywności i konkurencyjności oraz dynamiki i równowagi. Oczywiście nie należy stwierdzenia tego odczytywać jednostronnie, a więc jako sugestię do zarzucania racjonalności gospodarowania, przeciwnie, powinna być ona respektowana, lecz z poszanowaniem zasad etycznych.

\section{ZAKOŃCZENIE}

Z przeprowadzonych dotychczas rozważań wynika, że w istocie etykę instytucji państwowych można rozpatrywać na co najmniej dwa sposoby: jako przedsięwzięcie analizujące to, co znajduje się w piśmiennictwie, albo przedstawiać je z punktu widzenia poziomu etycznej świadomości społecznej i działań instytucji w tym obszarze. Nie sa to, rzecz jasna, tryby rozłączne, skoro bowiem zajmuje określone miejsce w naukowych rozważaniach oraz $\mathrm{w}$ debacie publicznej, zbiór ten bez watpienia stanowi użyteczne scalenie teorii i praktyki. O wiele jednak bardziej istotne podczas analizy tego problemu wydają się kwestie dotyczące skutków działań nieetycznych w wymiarze instytucji państwowych oraz profilu zainicjowania przedsięwzięć, które wyeksponowałyby odpowiedzialność osobistą wszystkich podmiotów. Nie jest jednak możliwe, by w skomplikowanej, powiązanej wzajemnie w różnych konfiguracjach rzeczywistości przewidzieć wszystkie sytuacje i narzucić sztywne zasady moralne i etyczne podmiotom gospodarczym. Dlatego wielu naukowców zajmujących

${ }^{18}$ Ch. Lindblom, Politics and Markets: The World's Political Economic System, Basic Books, New York 1977, s. 172-173.

${ }^{19}$ H. Zboroń, Czy ekonomiści wierza jeszcze w wolny rynek?, „Prakseologia” nr 157, t. 2/2015, s. 34; B. Pogonowska, Czy ekonomiści wierza jeszcze w wolny rynek?, ibidem, s. 59-60; G. Krzymieniewska, Etyczne uzasadnienie praktyki negocjacji, w. B. Pogonowska (red.), Elementy etyki gospodarki rynkowej, PWE, Warszawa 2004, s. 207-208. 
się etyką biznesu za cel teorii moralności przyjmuje ustalenie i utrzymanie pewnych naczelnych zasad, które moga konstytuować fundament moralności. Z podobnego założenia wyszedł Joseph R. DessJardins, który utrzymuje, że nie mogą powieść się próby instytucjonalizacji odpowiedzialności etycznej np. wewnątrz przedsiębiorstwa, które nie będą oparte na pewnych ogólnych zasadach. Przemawiaja za tym - jego zdaniem - powody zarówno praktyczne, jak i teoretyczne:

- Zasady etyczne rzadko daja jednoznaczne rady praktyczne. Pojawia się bowiem nieskończony ciag problemów, gdy z takich zasad, jak imperatyw kategoryczny czy reguła użyteczności, usiłujemy wyprowadzić rozwiąania zagadnień etycznych, przed którymi stoją ludzie biznesu. Jeszcze większy zamęt powstaje, gdy do dyskusji włączy się zalecenia wynikające z konkurujących zasad. Ci, którzy próbowali uczyć etyki biznesu w ten sposób, moga zaświadczyć, że etyka to nie mechanika - jednoznacznie poprawne lub choćby ogólnie akceptowane odpowiedzi zdarzaja się bardzo rzadko. Zdecydowana niekonkluzywność dyskusji etycznych powinna co najmniej sugerować, że coś jest nie $\mathrm{w}$ porządku w naszym podejściu do problemów moralnych.

- Żadna zasada etyczna nie ustaliła się jeszcze w zadowalającej postaci jako obowiązująca wszystkich ludzi. Po prostu filozofom nie udało się uargumentować zasad, które stosują w etyce biznesu. A próby instytucjonalizacji odpowiedzialności moralnej przez odwołanie się do jakiejś zasady bez uprzedniego i niezależnego jej umotywowania nie powiodą się. Nic tu nie dadzą teorie moralności oparte na zasadach ${ }^{20}$.

Należy także zwrócić uwagę na jeszcze jedną ważna, lecz często pomijaną kwestię, mająca jednak duży wpływ na pozytywny lub negatywny efekt wynikający z podjętych działań w sferze odpowiedzialności etycznej wszystkich podmiotów, związaną $\mathrm{z}$ wydatkami na te cele $\mathrm{w}$ trakcie konstruowania budżetu. Otóż problem dotyczy badań i analiz koordynujących sferę instytucjonalną $\mathrm{z}$ realna gospodarką $\mathrm{w}$ celu wykazania kosztów i korzyści wynikających $\mathrm{z}$ wprowadzenia i przestrzegania nie tylko przepisów prawnych, lecz również aspektu aksjologicznego, tak jak to czyniono w latach sześćdziesiątych XX w. do oceny celowości wydatków publicznych w takich dziedzinach, jak efektywność studiów wyższych czy program zwalczania chorób zakaźnych. Technika ta, nawiązująca bezpośrednio do analizy wydatków publicznych, nie jest ani prosta, ani niekontrowersyjna, choć związane z nią intuicje mają często dość zdroworozsądkowy charakter. W gruncie rzeczy intuicje te sugeruja, że warto porównywać łączne koszty określonego przedsięwzięcia z łącznymi, płynącymi zeń korzyściami po to, aby przekonać się, czy alokacja zasobów jest efektywna, a zatem czy łączne korzyści przekraczaja łączne koszty ${ }^{21}$. Ten sposób określania korzyści ma jednak wady. Podstawowym problemem jest oszacowanie korzyści w jednostkach pieniężnych. Przy tym obliczenie korzyści lub kosztów wynikających z etycznego lub nieetycznego zachowania pojedynczych

${ }^{20}$ M. Hoffman et al. (eds.), Corporate Governance and Institutionalizing Ethics, Lexington Books, Lexington, Mass. 1984, za: G. D. Chryssides, J. H. Kaler, Wprowadzenie do etyki biznesu, PWN, Warszawa 1999, s. 143-144.

${ }^{21}$ B. Szlachta (red.), Stownik społeczny, WAM, Kraków 2004, s. 215. 
przedsiębiorstw, choć trudne, to jednak jest możliwe do oceny np. nadużyć wobec zakładów ubezpieczeń, określenia strat będących następstwem oszustw podatkowych, malwersacji, nieprawidłowo przeprowadzonych przetargów czy wyłudzeń. O wiele więcej trudności przysparza jednak oszacowanie pozaekonomicznych kosztów wynikajacych np. z konsekwencji braku odpowiedzialności reprezentantów instytucji państwowych, rosnącej polaryzacji dochodów, konsekwencji wynikających z przekonania o braku kontroli i bezkarności czy degradacji środowiska naturalnego. Ustalenie tych kosztów nie jest wcale łatwe i z reguły trzeba poprzestawać na nader niedoskonałych szacunkach ${ }^{22}$. Niemniej efekty z tym związane zależą głównie od stanu wiedzy etycznej społeczeństwa i przestrzegania norm etycznych przez wszystkich uczestników rynku, zarówno w skali lokalnej, krajowej, jak i międzynarodowej.

Zagadnienie kosztów podejmował także Joseph E. Stiglitz, wiążąc te kwestie z pracami Międzynarodowego Funduszu Walutowego (MFW). Wskazuje on, że oprócz strategii rozwojowych dla biednych, MFW nie oszacował tak ważnych zagadnień, jak długoterminowe koszty społeczne i polityczne programów rujnujących klasę średnia, a wzbogacających jedynie nielicznych na samej górze. Zarazem MFW przeszacował korzyści płynące z polityki opartej na fundamentalizmie rynkowym. Klasa średnia tradycyjnie była grupą dążącą do rządów prawa, do upowszechnienia oświaty, do stworzenia systemu zabezpieczeń społecznych. Są to podstawowe elementy zdrowej gospodarki, toteż erozja klasy średniej prowadziła do towarzyszacej jej erozji poparcia dla tych ważnych reform ${ }^{23}$.

Gros krajów na zwiększone ryzyko gospodarcze i osłabienie zaufania do instytucji krajowych, międzynarodowych i biznesu naraziła także globalizacja. Ryzyko to w nieproporcjonalnie dużym stopniu ponosiły głównie państwa mniej rozwinięte i zamożne, m.in. takie jak Polska. Przede wszystkim jednak w krajach tych za eliminowaniem ryzyka nie nadążała zdolność do tworzenia instytucji, w tym skutecznych systemów zabezpieczeń, które byłyby w stanie się z nimi uporać. Powstało nawet fałszywe przeświadczenie, że opodatkowanie bogatych blokuje gospodarkę. Przeczy temu jakość życia w Skandynawii i Niemczech, w których dobrze rozwijają się gospodarki stosujące wysokie opodatkowanie wysokich dochodów. Dlatego przeobrażenia promujace etyczne zasady gospodarowania powinny być ukierunkowane na integrację i zmiany kulturowe. Szansą na przemiany uwzględniające warunki społeczne, w jakich to gospodarowanie przebiega, jest określenie reguł etycznych oraz transformacji mającej na względzie:

- Zmiany społeczno-gospodarcze w kierunku propagowania zasad etycznego gospodarowania, które powinny zaczynać się od najwyższego szczebla państwowego. Na tym poziomie ma to bowiem duży ładunek symboliczny, który efektywnie może pobudzać przemiany, ponieważ zmiana na najwyższym poziomie wyznacza jej rangę oraz sygnalizuje o wadze problemu.

${ }^{22}$ G. Wolska, CSR jako wspótczesna koncepcja prowadzenia działalności gospodarczej, w: J. Sokołowska, M. Rękas, G. Węgrzyn (red.), Zaangażowanie w ideę CSR przedsiębiorstw $w$ Polsce, Wyd. UEWr, Wrocław 2014, s. 539.

${ }^{23}$ J. E. Stiglitz, Globalizacja, PWN, Warszawa 2004, s. 87-88. 
- Stworzenie instytucji odpowiedzialnych za zmiany społeczne i promujących wdrażanie społecznej odpowiedzialności biznesu oraz przestrzeganie norm etycznych i moralnych, przy czym powinny być to instytucje niezależne od partii politycznych. Eliminuje to naciski i uwikłanie w nieformalne związki blokujace transformacje, często niewygodne dla przedstawicieli biznesu.

- Wdrażanie programów społecznych, zwłaszcza tych propagujących etyczne reguły życia społeczno-gospodarczego. Plany te powinny być zakomunikowane całemu społeczeństwu poprzez media i szkolenia. Potrzebna jest przede wszystkim spójna, realna i praktyczna infrastruktura etyczna skierowana do całego społeczeństwa, obejmująca wszystkie środowiska. Społeczeństwo powinno również otrzymywać bieżące informacje o zaawansowaniu zmian.

Zaprezentowane nowelizacje musiałyby być wdrożone we wszystkich możliwych relacjach działalności gospodarczej, ponieważ dopiero wówczas mogłyby przynieść zamierzony efekt.

dr hab. Grażyna Wolska

Profesor Uniwersytetu Szczecinskiego

grazyna.wolska@wzieu.pl

\title{
ETHICALITY OF THE BEHAVIOUR OF THE OFFICERS OF STATE INSTITUTIONS AND THE REPRESENTATIVES OF BUSINESS
}

\begin{abstract}
Summary
In a market economy, the main task of state institutions is to reduce uncertainty by setting frameworks that affect actions and decisions of all the actors in the market. The effectiveness of the implementation of socio-economic strategies and plans depends on the efficiency of the system adopted and its coherence. Ineffective and unethical institutions may lead to an accumulation of pathological phenomena. On the one hand they hinder the free, and not unreasonably restricted, development of all actors in the market, and on the other hand they may lead to a situation in which the uncontrollable symptoms of 'animal instinct' will come into play, provoking irrational, too risky or even harmful behaviours. This in turn raises the need to develop state mechanisms that reconcile the requirements of economic, social and political efficiency whilst at the same time respecting ethical standards. The aim of the study presented in this article was to demonstrate that the correlation between ethically acting of representatives of state institutions and the ethical behaviour of business representatives is not sufficiently recognised and appreciated, and that the introduction of a system of ethics, consisting of objective assessments, implies the ethical selfregulation of socio-economic entities and of the economic development of the state.
\end{abstract}


